\title{
EL SENTIDO MORAL DEL PENSAMIENTO DEMOCRÁTICO ESPAÑOL A MEDIADOS DEL SIGLO XIX
}

\author{
JOAQUÍN VARELA SUANZES \\ Catedrático de Derecho Constitucional \\ Universidad de Oviedo
}




\section{SUMARIO}

1. LOS "DEMÓCRATAS» COMO "TENDENCIA CONSTITUCIONAL". 2. EL SUPUESTO "CONTENIDO ÉTICO" DEL LIBERALISMO ESPAÑOL Y SU TRASFONDO HISPÁNICO. 3. SOCIALISMO UTÓPICO Y DEMOCRACIA. 4. CRISTIANISMO Y DEMOCRACIA. 


\title{
EL SENTIDO MORAL DEL PENSAMIENTO DEMOCRÁTICO ESPAÑOL A MEDIADOS DEL SIGLO XIX
}

\author{
POR \\ JOAQUÍN VARELA SUANZES \\ Catedrático de Derecho Constitucional \\ Universidad de Oviedo
}

1. LOS «DEMÓCRATAS» COMO «TENDENCIA CONSTITUCIONAL»

Desde 1814 a 1845 se produjo en el liberalismo español un notable giro conservador, que afectó tanto a «moderados" como a "progresistas", aunque no de la misma manera, y que se plasmó en los tres textos constitucionales que estuvieron en vigor durante este período. Las experiencias del "Trienio constitucional" y de los exilios, la presión internacional de la Santa Alianza, primero, y. de la Cuádruple Alianza, después, la recepción del pensamiento constitucional de la Europa post-napoleónica, la Guerra carlista, la Desamortización, el deseo de adaptar el Estado constitucional a la organización social y económica de España así como a la de la Europa más avanzada, sobremanera a la Gran Bretaña y Francia, fueron las principales causas que explican el giro conservador del constitucionalismo español durante la primera mitad del siglo XIX y el consiguiente abandono de la teoría y del modelo constitucional del liberalismo doceañista.

Pero durante el "Trienio Constitucional" y sobre todo tras la muerte de Fernando VII, en 1833, hubo un grupo de liberales que, lejos de vaciar la carga revolucionaria del liberalismo doceañista, la refor- 
zaron todavía más, democratizándola y agregándole determinados principios que procedian de una tradición intelectual ausente en las Cortes de Cádiz. Durante las décadas centrales del siglo XIX se manifiesta, así, una tendencia constitucional -esto es, un grupo de hombres unidos entre sí por unas ideas afines en torno a la organización jurídica del Estado y a las relaciones entre éste y la sociedad, se agrupen o no en un mismo partido político - distinta de la que formaban los "moderados" y los «progresistas». Esta tendencia era la que formaban los "demócratas»".

Los "demócratas" hicieron acto de presencia en la vida española a partir de una doble crítica: a la Desamortización, de acuerdo con las tesis que sostuvo Álvaro Flórez Estrada, y a la Constitución de 1837, elaborada por los "progresistas", pero con muchas concesiones a los "moderados" y tras atenuar las consecuencias algunos principios de la Constitución de Cádiz, como el de soberanía nacional. Los «demócratas", que ya actúan como tales durante el trienio esparterista, se organizan en 1849 en un partido político propio, en el que confluyen hombres que proceden de las filas del partido progresista, miembros de grupos republicanos y federales así como militantes de grupos afines al socialismo utópico. Los "demócratas" tenían como objetivo común la transformación democrática del Estado liberal diseñado por "moderados" y "progresistas", sin necesariamente poner en entredicho la Monarquía ni la propiedad privada, aunque muchos de ellos siguiesen defendiendo la República Federal y otros el socialismo².

1 Sobre las diversas «tendencias constitucionales» durante la primera del siglo XIX español, vid. Joaquín VARELA SUANZES, "La Constitución española de 1837: una Constitución transaccional», Revista Española de Derecho Político, n. 20 , Madrid, 1984, págs. 95-106; "La Constitución de Cádiz y el Liberalismo español del siglo XIX", Revista de las Cortes Generales, n. ${ }^{\circ}, 10$, Madrid, 1987, págs. 94 y ss., "El Pensamiento Constitucional Español en el Exilio: el abandono del modelo doceañista (1823-1833)", Revista de Estudios Políticos (en adelante, REP), n. ${ }^{\circ} 87,1995$, págs. 63-90; "La Monarquía Imposible. La Constitución de Cádiz de 1820 a 1823", Anuario de Historia del Derecho Español, tomo LXVI, Madrid, 1996, págs. 653-68; "El Debate sobre el sistema británico de gobierno en España durante el primer tercio del siglo XIX", en José María IÑURRETEGUI y José María PorTILLo (eds.), Constitución en España: orígenes y destinos, Centro de Estudios Políticos y Constitucionales (en adelante, CEPC), Madrid, 1998, págs. 79-108.

2 Sobre el Partido Demócrata español y sus antecedentes, vid. Antonio EIRAS RoEL, El partido demócrata español (1849-1868), Rialp, Madrid, 1961, passim; Mateo DEL PERAL, "Liberalismo y democracia en España, algunos testimonios anteriores a 1840 ", en Estudios de Ciencia Política y Sociología en Homenaje a Profesor Carlos Ollero, Madrid, 1972; y Miguel ARTOLA, Partidos y programas políticos, 1808-1936, Alianza Editorial, Madrid, 1991, vol. I, págs. 251-254 y 274-278. 
Los "demócratas» desempeñaron un papel destacado de 1854 a 1856, durante el llamado "Bienio progresista", y sobre todo durante el sexenio de 1868-1874, que no en vano se denomina "sexenio democrático" o "revolucionario", y en su pensamiento se encuentra la inspiración doctrinal más importante del texto constitucional más avanzado de nuestro siglo XIX, el de 1869, así como del proyecto de Constitución Federal de 1873. Es verdad que la revolución de 1868 fue, en el plano político, el resultado de un acuerdo entre el partido progresista, el partido democrático y la Unión Liberal, un partido este último formado por algunos "moderados» escindidos por la izquierda, los antiguos "puritanos», y por "progresistas» de derecha. Un acuerdo propiciado por la marginación política de los "progresistas" desde 1856, que les llevó a "retraerse" en 1863, al igual que a la Unión Liberal en 1866. Esta alianza interpartidaria se había ido formalizando en 1866 durante la llamada "Asamblea de Ostende" y un año después en el denominado "Pacto de Bruselas". Pero no es menos cierto que la revolución de 1868 fue, en el plano ideológico, obra sobre todo del partido demócrata, aunque su programa no se plasmase por entero en la Constitución que se aprobó al año siguiente, como se verá a lo largo de estas páginas. La "Gloriosa" fue, así, una auténtica revolución democrática y no un pronunciamiento más, de los muchos que había habido hasta entonces desde el alzamiento juntista de 1808. Esta revolución supuso el último intento de llevar a cabo el programa que habían diseñado las Cortes de Cádiz, sin recortes e incluso radicalizando su contenido.

La teoría constitucional que defendieron los "demócratas" durante los años centrales del siglo XIX, al menos la que era común a sus tres tendencias internas (la monárquico-individualista, la republicano-federal y la socialista, que se escindieron orgánicamente a partir de 1868), siguió representando años después la más relevante alternativa al constitucionalismo liberal, pero no democrático, de la Restauración, y sus principios se recogieron, de forma todavía más plena que en 1869, en la Constitución de 1931 y en la vigente Constitución de 1978, pese a lo cual sus más destacados representantes, como Castelar, Garrido o Pi i Margall, no han sido recordados en nuestros días como merecen, y desde luego sus nacimientos o sus muertes se han conmemorado oficialmente mucho menos que los de otros liberales conservadores, más alejados de los principios en los que se asienta nuestra Constitución, como Cánovas del Castillo.

En las páginas que siguen se tratará de examinar el pensamiento constitucional de los "demócratas" desde la reforma constitucional de 1837 a la revolución de 1868. Muy en particular, se tratará de poner de 
relieve uno de los rasgos más característicos de este pensamiento: su moralismo, que les llevó a reflexionar sobre la política y la Constitución desde la exaltación de la libertad, la tolerancia, la justicia y la igualdad, con una constante preocupación, idealista y generosa, por mejorar las condiciones de vida del ser humano. Este intenso sentido moral de los "demócratas" españoles es un rasgo que sin duda hundía sus raíces en la historia intelectual española, pero obedecía también al influjo de dos corrientes doctrinales, reelaboradas fuera de nuestras fronteras: el socialismo utópico y un cristianismo evangélico o primitivo, bien distinto del catolicismo oficial predominante en la Europa de entonces.

Veámoslo.

\section{EL SUPUESTO «CONTENIDO ÉTICO» DEL LIBERALISMO ESPAÑOL Y SU TRASFONDO HISPÁNICO}

José Luis Abellán se ha referido al "contenido ético" como una de las características más sobresalientes del liberalismo español. En apoyo de esta tesis recuerda este autor la etimología castellana del vocablo "liberal", como cualidad que denota tolerancia, generosidad $y$ desprendimiento, y que en España se proyectó sobre la acepción política del término "liberal", que tuvo su origen en nuestro país durante las dos primeras décadas del siglo pasado, aunque sobre este particular las opiniones al respecto no coincidan ${ }^{3}$. El liberalismo habría sido, así, en España no sólo una ideología relativa a la organización del Estado y de la sociedad, sino también una doctrina exaltadora de la libertad y dignidad del ser humano. "El originario sentido de "liberal», como persona generosa y tolerante se involucró en su significado político, dándole un carácter predominantemente moral a la nueva acepción de la palabran ${ }^{4}$.

A juicio de Abellán, este fenómeno, ciertamente significativo, es preciso conectarlo con el fondo religioso que anima a tantas concepciones españolas y muy en particular era una manifestación de la

3 Sobre este extremo vid. Juan MARICHAL, "Liberal"; su cambio semántico en el Cádiz de las Cortes", en El Secreto de España, Taurus, Madrid, 1995, págs. 29-35.

4 José Luis Abellan, Historia Crítica del Pensamiento Español, vol. IV. Liberalismo y Romanticismo, Espasa-Calpe, Madrid, 1984, págs. 59-60. 
"negación de la religión del éxito» ${ }^{5}$, que para este autor es una de las notas más destacadas que caracterizan al pensamiento español desde la Edad Media, como sostiene a lo largo de los cuatro tomos de su Historia Crítica del Pensamiento Español, que puede considerarse una réplica actualizada, rigurosa y progresista de la Historia de los Heterodoxos Españoles, de Marcelino Menéndez Pelayo.

A mi parecer, sin embargo, sólo resulta adecuado hablar del "contenido ético" del liberalismo español si se identifica este liberalismo con el doceànista y sobre todo con el posterior liberalismo democrático. Pero tal identificación no es aconsejable. No hay un solo liberalismo español, como tampoco lo hay en Europa, sino varios. $Y$ ni el liberalismo de los "progresistas" ni mucho menos el de los "moderados" destacó por su "contenido ético". Por otro lado, el innegable "contenido ético" del liberalismo doceañista y democrático fue una nota común al liberalismo revolucionario y democrático del resto de Europa. Recuérdese a este respecto el intenso moralismo del liberalismo francés de 1793, influido por Rousseau, con su. hincapié en la virtud y en el civismo (Robespierre es un buen ejemplo) y su desprecio hacia el liberalismo elitista y aristocrático de Voltaire y Montesquieu, así como el no menor sentido moral y humanitario del liberalismo democrático francés del cuarenta y ocho, al que correspondió exhumar en gran medida el programa del noventa y tres, por otro lado tan ambivalente, al aunar un intenso contenido ético y filantrópico con un componente fanático y redentor, en extremo peligroso para la libertad y el pluralismo. Si de Francia pasamos a la Gran Bretaña, viene muy a cuento recordar el liberalismo radical de Thomas Paine y el socializante de John Stuart Mill, ambos con una notable carga moralizante.

Ahora bien, es verdad que el liberalismo doceañista y sobre todo el democrático posterior presentan un contenido moralizador todavía más extenso e intenso que el del resto de Europa, como ha puesto de relieve Antonio Ramos Oliveira, aunque este historiador amplíe también este rasgo a todo el liberalismo español: "por todos conceptos, nada hay en Europa que equivalga al liberalismo doceañista español. La voz liberal designa en la política española una actitud moral, mientras que en Europa la recoge para definir valores políticos y económicos engendrados por una nueva clase social que en España no existía. Nótese que España no queda dividida en liberales y conservadores,

5 Ibidem, pág. 60. 
sino en liberales y serviles. El liberal español se autodefine por el nombre que pone a su antagonista, y al llamarle servil lo elimina como ente político para exaltarlo como sujeto moral. Liberales y serviles, exaltados y moderados: conceptos morales. Esta original concepción del conflicto se reflejará en toda la política liberal española, más atenta a imponerse al adversario por la dignidad que por la eficacia. $Y$ más interesada en humillarlo que en destruirion. 6 .

Insistiendo en este diferente perfil del liberalismo español en relación con el europeo, Luis Díez del Corral escribe: «no; nuestros liberales no serán verdaderos burgueses, esos burgueses europeos comedidos, utilitarios y sensatos; nuestros liberales continuarán viendo el mundo desde una perspectiva que, por secularizada que esté, sigue siendo la del hidalgo español, un hidalgo disparatadamente quijotesco que en la aurora entusiasta del gran capitalismo continúa luchando con los molinos y se muestra sobrecogido por los batanes, y que mientras los europeos de su tiempo se afanan en traer una prosperidad insospechada a su país, él lo destroza, lo desangra y lo despedaza, movido por un anhelo insaciable, alto, digno, trágico, que, como caído de un mundo superior, no puede satisfacerse con los bienes de éste»?.

Tanto Abellán, como Ramos Oliveira y Díez del Corral parecen olvidar, sin embargo, que el liberalismo español más influyente del siglo XIX no se mostró ciertamente muy idealista y quijotesco, sino todo lo contrario: sensato, pragmático, comedido, ecléctico. Un liberalismo que vertebró un Estado constitucional para un sector muy minoritario de la población (la de los varones contribuyentes), excluyendo al resto, y que impulsó la desamortización con un espíritu poco generoso, enriqueciendo a los ricos y empobreciendo a los pobres, lo que a la postre se volvió contra el propio liberalismo, al restarle apoyo popular.

Los "demócratas» (que, por serlo, eran también liberales, incluso, como se verá más adelante, los que procedían de grupos afines al socialismo utópico), mucho más todavía que los doceañistas, sí estaban impregnados, en cambio, de un intenso moralismo. $Y$ este rasgo les distinguía notablemente de los "progresistas" y mucho más toda-

6 Antonio Ramos Olivelra, Historia de España, Tomo II, Compañia General de Ediciones, S. A. México, págs. 184-185.

7 Luis Diez DEL CORRAL, El liberalismo doctrinario, Instituto de Estudios Políticos, 3. ${ }^{\circledR}$ edición, Madrid, 1973, pág. 485. 
vía de los "moderados» durante la España isabelina. Este rasgo de los "demócratas", sobremanera de los que abrazaron el ideal republicano y federal, lo ha subrayado Antonio Elorza en su estudio sobre la organización e ideología del federalismo español de los años treinta y cuarenta del siglo XIX, que este autor ha llevado a cabo a partir de un minucioso análisis de la prensa y de los textos doctrinales de sus más importantes representantes. "La República -escribe Elorza - no sólo encarna la supresión del absolutismo, la reforma de la condición obrera y el mantenimiento de ideal cristiano de la redención, sino que comporta el fin de los excesos del Estado centralizado. Austeridad, moralidad y economía son las tres notas dominantes que la propaganda democrática exalta en un principio en el sistema republicano...." ${ }^{8}$.

Tal actitud, sin embargo, no condujo a los «demócratas»a abandonar los criterios utilitarios y en particular los de Bentham, que tanta influencia habían ejercido entre los "progresistas" y los "moderados", sino a interpretar el utilitarismo sub specie moralitatis, como en la cuna de esta doctrina hizo John Stuart Mill. Un buen ejemplo de esta interpretación se encuentra en El Peninsular, un periódico republicano que se publica en 1842, que transforma el benthamismo en doctrina de la democracia universal, al extender el principio de "la mayor dicha del mayor número" a todos los hombres. Asimismo, la República se concibe como un sistema "político-moral», pues, como afirma este periódico, "la política será para nosotros la moral aplicada al gobierno de los pueblos" 9 .

El moralismo fue una nota común de los "demócratas" españoles, ya fuesen monárquicos o republicanos, federalistas o unitarios, socialistas o individualistas, además de un rasgo que caracterizó a la revolución de 1854 y sobre todo a la de 1868. Esta última se quiso justificar por la estrechez política del modelo "moderado" establecido en 1845, que, como queda dicho, había obligado a la oposición a "retraerse", pero también por la inmoralidad de los gobernantes - incluida la propia familia real - en la gestión de los asuntos públicos, sobre todo en materia urbanística y en la construcción de ferrocarriles, que tanto benefició a personajes como Sartorius y Salamanca, e incluso por la inmoralidad privada de la mismísima Reina,

8 Antonio ELoRZA, «La primera democracia federal: organización e ideología", en Juan J. Trías y Antonio EloRZA, Federalismo y reforma social en España (1840-1870), Seminarios y Ediciones, Madrid, 1975, pág. 86.

9 Ibidem, págs. 143-144. 
debido a su desordenada vida sentimental. De José Luis Aranguren son estas palabras sobre el sentido moral de los revolucionarios de 1868: "por sectarios, antirreligiosos y aun declaradamente ateos que fuesen muchos de los revolucionarios, el impulso moral y hasta un cristianismo antidogmático e interior... era no sólo muy perceptible, sino que, unido al moralismo, fue uno de los elementos de aquella ideología..." Una ideología que Aranguren no duda en calificar de "generosa e idealista" ${ }^{10}$. Como muestra de este moralismo revolucionario, de este espíritu filantrópico, recuerda este autor que los constituyentes de 1869 abolieron la esclavitud y la pena de muerte, emprendieron la reforma penitenciaria (que ya se había diseñado en Cádiz), abogaron por mejorar las condiciones de vida de la clase trabajadora y se manifestaron a favor de la promoción sociocultural, no todavía política, de la mujer ${ }^{11}$.

\section{SOCIALISMO UTÓPICO Y DEMOCRACIA}

Sin minusvalorar su ya comentado trasfondo hispánico, el carácter moralizador de los «demócratas» españoles se explica también por el influjo del socialismo utópico europeo, sobre todo del francés: de Charles Fourier y Etienne Cabet, principalmente, y en menor medida de Lammennais, Saint-Simon y Louis Blanc. La influencia del inglés Owen fue mucho menor. Otros socialistas utópicos de segunda fila, como Alban de Villeneuve, Pecqueur y el Barón de Collins influyeron en Ramón de la Sagra, el más original, acaso el único, de los socialistas utópicos españoles, aunque más que socialista utópico este curioso y contradictorio pensador gallego era un «reformador social», como en su día lo calificó Núnez de Arenas, alejado además del pensamiento democrático en su crítica al gobierno de la mayoría y al sufragio universal ${ }^{12}$. Sólo Fourier y Cabet lograron formar escuela propia en Espana. Fourieristas fueron Joaquín Abreu, Fernando Garrido y Sixto Cámara, por citar a los más importantes, y cabetianos lo fueron los catalanes Narcís Monturiol, Abdón Terradas y José Anselmo Clavé. Unos y otros contaron con medios propios de expresión, en lo cuales insertaban en

10 José Luis Aranguren, Moral y Sociedad. Introducción a la moral social española del siglo XIX, Edicusa, 5. ${ }^{2}$ edición, Madrid, 1974, págs. 151-2.

11 lbidem, págs. 152 y ss.

12 Cfr. José Luis ABELLAN, Liberalismo y romanticismo, op. cit., págs. 610-

615. 
muchas ocasiones fragmentos de los textos principales de sus maestros franceses ${ }^{13}$.

Aunque la recepción del socialismo utópico había comenzado durante el Trienio de 1820 a 1823 y sobre todo durante el exilio de 1823 a 1833, su apogeo en España, al igual que en Europa, tuvo lugar de 1835 a 1854. El fracaso de la revolución europea de 1848, inspirada en buena medida en el utopismo radical y socialista, asi como la escasa fortuna de las experiencias comunales de Cabet y Owen, marcaron el comienzo del fin del socialismo utópico, que a partir de entonces entró en un período de lánguida decadencia. En la década de los cincuenta el socialismo utópico se sustituyó por el Bakuninismo y el marxismo, que en España se difundieron durante la década de los sesenta y sobre todo durante el sexenio revolucionario de 1868 a 1874 . Los sueños falansterianos, la búsqueda de las Icarias, renovación en parte de las viejas utopias platónicas $y$ renacentistas de Tomás Moro y CampaneIla, de las Arcadias y Eldorados, así como de las fantasias dieciochescas de Mably y Morelly, se sustituyen por otros proyectos de acción violenta y revolucionaria en pos de un comunismo libertario o de otro, no tan libertario, diseñado por mentes más "científicas", "positivistas" $y$, ciertamente, más eficaces.

En España, a partir de 1849, los más destacados socialistas utópicos se integraron en el Partido Democrático, conformando a partir de entonces su ala izquierda, desde la cual polemizaron durante los años cincuenta y sobre todo durante los sesenta con los demócratas «individualistas», del estilo de Orense, Rivero y Castelar ${ }^{14}$. De ahí que el estudio del pensamiento democrático español no pueda hacerse sin

13 Sobre el socialismo utópico español, vid. Antonio Elorza, Introducción y selección de textos a Socialismo utópico español, Alianza, Madrid, 1970; ídem, Sixto Cámara y el primer socialismo español, en Teoría y Sociedad, Ariel, BarceIona, 1970; ídem, Selección de textos y "Estudio Preliminar" a El Fourierismo en España, Ediciones de la Revista del Trabajo, Madrid, 1975; Jordi MALUQUER DE MOTES Bernat, El Socialismo en España (1833-1868), Barcelona, 1977; José Luis ABELLAN, Historia Crítica del Pensamiento Español, op. cit., tomo IV, cap. XXV, La trayectoria del socialismo utópico, págs. 601 y ss., además de las obras de Iris M. ZAVALA Y Eliseo AJA que se citan más adelante.

14 De particular importancia fue la polémica que, en 1860, protagonizaron Orense y Garrido sobre la compatibilidad de la democracia con el socialismo, que concluyó, por iniciativa de Pi y Margall, con la llamada "Declaración de los Treinta", en donde se exponían los puntos considerados esenciales del ideario democrático, entre los que se encontraban el sugrafio universal y los "demás principios fundamentales consignados en el programa democráticon, apud. Miguel ARTOLA, Partidos y programas politicos, op. cit., vol. l, págs. 274-275. 
tener en cuenta el influjo del socialismo utópico, incluso también en lo que atañe a su intensa carga moralizante.

El socialismo utópico español, en efecto, acaso todavía más que el europeo, se caracterizó por su dimensión ética. No era un socialismo revolucionario. No se proponía destruir el orden burgués y capitalista, por lo demás apenas esbozado en España, ni mucho menos el Estado liberal, sino, en primer lugar, acelerar la transición del Antiguo régimen al nuevo y, en segundo lugar, procurar que este tránsito fuese lo menos traumático para las clases trabajadoras. Los socialistas utópicos españoles predicaban una especie de armonismo social entre el capital, el trabajo y el talento, y defendían la creación de sociedades de resistencia y de ayuda, de seguros mutuos y de crédito, así como el fomento de escuelas obreras, de sociedades de socorro y otras iniciativas de similar naturaleza. Su eco fue, como es lógico, mucho mayor donde el proceso industrializador estaba más avanzado, como en Cataluña y, en menor medida, en Madrid: allí estuvo el grupo cabetiano; aquí el fourierista. En la década de los cincuenta los socialistas españoles se volcaron sobre todo en impulsar el asociacionismo obrero, configurando la prehistoria del sindicalismo español y la toma de conciencia de clase por parte de las clases trabajadoras.

El mayor interés del programa político-constitucional del socialismo utópico español residía, aparte de alguna esporádica defensa de los mecanismos de la democracia directa, como el referéndum, por parte de Garrido ${ }^{15}$, en que este programa incorporaba la defensa de lo que bastantes años más tarde se conocería como Estado social de derecho. El socialismo utópico español no fue, sin embargo, estatista. Las míseras condiciones de vida de las clases trabajadoras debía modificarse, a su juicio, más por una reforma de la sociedad y del sistema económico que por una intervención del Estado y desde luego por la "elevación moral e intelectual del pueblo". Sin embargo, el papel que asignaban al Estado no era el mismo que el que le había asignado los liberales del doce ni el que le seguía asignando la mayor parte de los "moderados" y "progresistas". El Estado ya no se consideraba como un elemento pasivo y abstencionista, según la más pura ortodoxia liberal, sino como un agente hasta cierto punto activo, que en determinadas áreas debía intervenir en la sociedad, entre otras cosas para ase-

15 Cfr. Luis Aguiar de Luque, Democracia directa y Estado Constitucional, Edersa, Madrid, 1977, pág. 239. Sobre el pensamiento de Garrido, vid. Eliseo AJA, Democracia y Socialismo en el siglo XIX. El pensamiento político de Fernando Garrido, Edicusa, Madrid, 1976. 
gurar lo que andando el tiempo se conocerían como los derechos económicos y sociales ${ }^{16}$. Los socialistas utópicos españoles, en efecto, además de exigir que se suprimiese el sistema impositivo indirecto $y$ regresivo implantado por Mon en 1845 y que se sustituyera el sistema de quintas por el servicio militar obligatorio, demandaron que la Constitución proclamase la gratuidad de la instrucción primaria y que el Estado se hiciese cargo de parte de la asistencia sanitaria. Unas exigencias plenamente coherentes con el ideal democrático y con el Estado Social de Derecho.

En realidad, no sólo los socialistas utópicos sino el resto de los demócratas, incluidos los "individualistas», compartían estas reivindicaciones, como lo prueba el que se recogiesen en el Manifiesto que el Partido Democrático Español elaboró en 184917. Como resalta Miguel Artola, en ese importante documento se pone de relieve «la preocupación por una intervención del Estado en las relaciones sociales, que constituye la primera ruptura con las tesis neutralistas del liberalismo clásico. La instrucción pública, la asistencia social y el sistema fiscal son los puntos en que consideran (los "demócratas») que la intervención estatal ha de producirse para paliar las desigualdades» ${ }^{18}$. Ninguna de estas reivindicaciones se plasmó, sin embargo, en la Constitución de 1869, que sí proclamó, en cambio, por primera vez en nuestra historia constitucional, dos principios consustanciales al ideario democrático: el sufragio universal, aunque sólo para los varones, y el derecho de asociación ${ }^{19}$. Habría que esperar a la II. República para que el nuevo papel intervencionista asignado al Estado por los «demócra-

16 El interés por la reforma social, no obstante, no era privativo de los socialistas utópicos. De este interés participaban en España todos los demócratas, incluso los "individualistas", además de algunos "progresistas" de izquierda, como Fermín Caballero y Joaquín María López, e incluso algún "moderado", como el siempre lúcido Andrés Borrego.

17 Este "Manifiesto" puede verse en Miguel ARTOLA, Partidos y programas políticos, op. cit., vol. II, págs. 37-45.

18 Miguel Artola, Partidos y programas políticos, op. cit., vol. l, págs. 251252.

19 El artículo 16 de esta Constitución decía: «Ningún español que se halle en el pleno goce de sus derechos civiles podrá ser privado del derecho de votar en las elecciones de Senadores, Diputados a Cortes, Diputados provinciales y Concejales». Por su parte, el artículo 27 añadia: «todos los españoles son admisibles a los empleos y cargos públicos según su mérito y capacidad...). El artículo 17, por su parte, reconocía el derecho de asociación en estos términos: «tampoco podrá ser privado ningún español:...del derecho de asociarse para todos los fines de la vida humana que no sean contrarios a la moral pública...". 
tas" se recogiese en una Constitución y para que, conforme a este nuevo papel, se reconociese en ella una nueva generación de derechos: los sociales y económicos.

\section{CRISTIANISMO Y DEMOCRACIA}

En el carácter moralizante del pensamiento democrático español tuvo mucho que ver, asimismo, la decisiva influencia que sobre este pensamiento ejerció el cristianismo. Antes de comprobarlo, conviene tener en cuenta la estrecha conexión entre socialismo utópico y cristianismo. Iris $M$. Zavala recuerda a este respecto que SaintSimon y sus discípulos habían aconsejado a menudo volver al cristianismo primitivo para mejorar la situación de las clases más pobres $^{20}$. Trae a colación Zavala las claras palabras de Zazard, uno de los discípulos de Saint-Simon, escritas en 1829 y recogidas en su "Exposición» de la doctrina de su maestro: "para nosotros, religión, política y moral son nombres distintos para un mismo hecho "21.También Cabet invocó el comunismo del cristianismo primitivo, mientras que Fourier sostuvo que la libertad individual llevaría a la armonía social sin necesidad de poderes espirituales o una Iglesia institucionalizada. Sus doctrinas atrajeron a muchos católicos, como Eugène Pelletan, Considérant y Abel Transon. Alphonse Esquiros llevará algo más lejos estás nociones; para él, Dios es el pueblo: en L'Évangile du peuple (1840) hizo las defensas más atrevidas del pueblo trabajador, en nombre del amor divino ${ }^{22}$.

La influencia cristiana se apreció en España sobre todo a través del belga Lamennais. Ya en 1834 Mariano José de Larra había traducido y prologado su libro Paroles d'un croyant ${ }^{23}$. En este Prólogo mostraba Larra su abierta simpatía hacia el cristianismo a la vez que un no menos franco anticlericalismo. Dos rasgos muy presentes en la teoría democrática española posterior. Larra, siguiendo a Lamennais, identificaba al cristianismo - a un cristianismo puro, evangélico - con el liberalismo e incluso con la democracia; "la religión cristiana -escri-

20 Cfr. Iris M. Zavala, Románticos y Socialistas. Prensa Española del siglo $X I X$, Siglo XXI de España, Madrid, 1972, pág. 131.

21 Ibidem, pág. 131.

22 Ibidem, págs. 131-132.

23 El dogma de los hombres libres. Palabras de un creyente, traducción y Prólogo de M. José de Larra, Imprenta de Julio Barite y Bouluch, Madrid, 1834. 
be- es una religión demócrata y popular ${ }^{24}$. Por ello, aunque como español era existencialmente católico, Larra se sentía más próximo intelectualmente al protestantismo que al catolicismo, en la medida en que aquél, con su insistencia en la interiorización de la fe, había mostrado una mayor facilidad para distanciarse del Estado y de la política $y$, por tanto, había engarzado mejor con el espíritu liberal25.

Esta actitud -que parecía olvidar la estrecha vinculación de las Iglesias protestantes al Estado, no ya en la Gran Bretaña, sino también en los países escandinavos - la mantuvieron otros liberales y demócratas españoles durante el siglo XIX, desde Blanco-White hasta Miguel de Unamuno, pasando por los krausistas, cuya espiritualidad laica estaba muy próxima al protestantismo.

La conexión entre cristianismo y democracia e incluso entre cristianismo y socialismo, unida a un indisimulado anticlericalismo, se halla en muchos de los más destacados "demócratas» españoles de mediados del siglo XIX. Por ejemplo, en Wenceslao Aiguals de lzco, el más genuino representante en España de la novela social iniciada por el francés Eugène Sue y una de las personas que más difundieron el ideal democrático y republicano a través de la prensa y de los folletones populares ${ }^{26}$. En un artículo publicado en El Huracán, el 3 de abril de 1841, Ayguals llegar a afirmar que «la República es emanación del cielo" y que "los Reyes son agentes del infierno", "imágenes del demonio» ${ }^{27}$. Para Ayguals el criterio de diferenciación entre monarquía República tiene, en último término, un carácter moral. Una y otra vez la República se define como un régimen de moralidad y de economía ${ }^{28}$.

El componente cristiano y anticlerical era patente también en José Ordax Avecilla, director de otro importante periódico democrático de principios de los años cuarenta, El Regenerador, cuyo principal rasgo consistía en ligar democracia política y fidelidad a un cristianismo primitivo, que, como era habitual entonces, se unía a la condena

24 Prólogo a El dogma de los hombres libres, op. cit., pág. 292.

25 Sobre las convicciones religiosas de Larra, vid. Susan KIRPATRICK, Larra: el laberinto inextricable de un romántico liberal, Gredos, Madrid, 1977, págs. 153-156.

26 AIguALS DE IzCo escribió "María, la hija de un jornalero" (1845), "La Marquesa de Bellaflor o el niño de la Inclusa" (1846-1847), "Pobres y ricos o la bruja de Madrid»( 1849), y "El Palacio de los crímenes o el pueblo y sus opresores" (1855). Sobre Aiguals, vid. Vicente Llorens, El Romanticismo Español, Fundación Juan March, Editorial Castalia, Madrid, 1979, págs. 592-594.

27 Apud A. Elorza, La primera democracia federal, op. cit., pág. 129

28 Cfr. ibidem, pág. 199. 
constante del "fanatismo" y del "exclusivismo sacerdotal" ejercido en el seno del catolicismo» ${ }^{29}$. A juicio de Ordax, la religión cristiana exigía la democracia, porque su primera condición es la igualdad ${ }^{30}$. En su escrito La política en España, pasado, presente y porvenir, publicado en el Madrid de 1853, Ordax volvía a insistir en el nexo entre cristianismo y democracia ${ }^{31}$ y lo mismo acontecía por las mismas fechas con Sixto Cámara 32 .

El nexo entre ideal democrático y cristianismo, así como un decidido anticlericalismo, están presentes también en La República democrática federal universal, publicado en 1848. Su autor, Fernando Garrido, señalaba que "las monarquías, a pesar de todos sus títulos de cristianas y católicas, son hoy vanas. La fraternidad, la caridad, la igualdad, proclamadas por Cristo son incompatibles con los tronos... la República democrática, federal y universal, es la más cristiana de todas las instituciones políticas; o mejor dicho, es la única institución verdaderamente cristiana: porque en ella la práctica de los grandes principios morales del evangelio se convierte dogma, en base de todos los derechos, de todas las leyes». Insistiendo en el contenido moral e incluso religioso de la democracia, añadía Garrido que "la libertad, la igualdad y fraternidad, principios religiosos y morales más que políticos, son la cúspide, el principio y el fin de las instituciones democráticas» ${ }^{33}$.

Garrido ensalzaba en este escrito las "máximas del evangelio» y tenía palabras muy duras para con los sacerdotes: «¿Quién reconocerá a un representante de la religión, a un discípulo de Jesucristo, que es todo amor, en un energúmeno vestido de negro sayo, que con una cruz en una mano y un puñal en la otra predica el exterminio de su hermano, y los extermina él mismo, como hace medio siglo estamos viendo todos los días de la católica España con escándalo del mundo civilizado? $n^{34}$.

29 Ibidem, pág. 130.

30 Cfr. ibidem, pág. 130.

31 Cfr. José Ordax Avecilla, La Política en España. Pasado, presente y porvenir, Madrid, 1853, pág. 3. cit., pág. 332.

32 Cfr. Antonio EloRza, Sixto Cámara y el primer socialismo español, op.

33 Fernando GARRIDO, "La República democrática federal universal. Nociones fundamentales de los principios democráticos dedicados a las clases productivas", Madrid, 1848, publicado como Apéndice en el libro de Juan J. Trías y Antonio EloRzA, Federalismo y Reforma Social en España, op. cit., pág. 392.

34 Fernando GARRIDO, La República democrática federal universal, ibidem, págs. 404-5. 
No dudaba Garrido en defender la libertad de cultos como principio consustancial tanto al auténtico cristianismo evangélico como al ideal democrático: "En el sistema republicano -escribe - los católicos practican libremente su religión; nadie tiene derecho a estorbarlos ni a oponerse a sus prácticas y devociones... con el sistema republicano, la religión no tiene más armas que las que le son propias; la persuasión y el ejemplo... En el sistema democrático, la administración pública no tiene nada que ver con la religión. Los fieles entienden directamente con el clero, al cual pagan espontáneamente el culto... La libertad de cultos, lejos de ser un mal es un bien para los pueblos....135.

La influencia de Lamennais en esta postura de Garrido no debe desdeñarse. José Antonio Maravall recuerda que en El socialismo y la Democracia ante sus adversarios, trabajo publicado en Londres, en 1862, Garrido confesaba que él mismo había puesto en manos del anciano Lamennais ejemplares de sus obras impresas secretamente por trabajadores españoles como testimonio de respeto y admiración, y que el «filósofo cristiano" gozó de ver penetrar sus ideas con los rincones de España ${ }^{36}$.

También el gran vate del republicanismo español del siglo XIX, Emilio Castelar reconocía en su Prólogo al libro de Garrido antes citado, La República democrática federal universal, haberse sentido atraido a la democracia desde el cristianismo: «La revolución de 1848 -escribe Castelar - aquel hermoso canto a la libertad... resonó en mi corazón de niño con tan deleitosa armonía, que inclinado por educación y por sentimiento a ideas religiosas... me apasioné por la democracia, creyendo ver en ella la realización del Evangelio... la Libertad, la Igualdad, la Fraternidad, ¿No son el reflejo de la Trinidad divina en el alma? Buscar en la sociedad remedios a esas clases desheredadas, esclavas de la miseria y de la ignorancia, ¿no es imitar a Jesús?».

La influencia del cristianismo en los "demócratas" españoles siguió durante los años sesenta. A este respecto señala Maravall que en torno a 1865 los demócratas y republicanos, como antes había ocurrido con los liberales, apelaban al cristianismo primitivo y se presentaban como los verdaderos representantes de la doctrina evangélica de Cristo. Cita este autor como ejemplo a Roque Barcia, quien en abril

35 lbidem, págs. 405-6.

36 José Antonio MARAVALL, «Sobre orígenes y sentido del catolicismo liberal en España", en Homenaje a Aranguren, Ed. Revista de Occidente, Madrid, 1972, págs. 265-6. 
de ese año afirmaba en La Democracia que "el sistema democrático es el único verdaderamente católico". También en 1865 Barcia publicó un libro cuyo título era bien revelador: Histórica, verdadera y fiel exposición de los grandes principios cristianos contra el falso catolicismo que nos devora ${ }^{37}$.

El influjo de Lamennais en esta actitud de los "demócratas" españoles es bien claro. El propio Maravall recuerda que entre 1836 y 1840 se tradujeron y publicaron en España varias obras de este autor, aparte de la ya citada Palabras de un Creyente, como El libro del pueblo y De la esclavitud moderna ${ }^{38}$. La influencia de Lamennais la detecta Maravall en el progresista de izquierda Joaquín María López ${ }^{39}$, y añade que en 1854 se publicó en Madrid una edición de "obras políticas" de Lamennais, incluida en la Biblioteca del Hombre Libre ${ }^{40}$.

Maravall identifica la actitud de muchos "demócratas» españoles de vincular el cristianismo y el ideal democrático con lo que este autor denomina "catolicismo liberal". Un catolicismo, a su juicio, que no consistía en conciliar el catolicismo y el liberalismo sino en mostrar que el primero conducía al liberalismo y, con más exactitud todavía, al liberalismo democrático. Esta tesis tenía en España, a juicio de Maravall, su primer precedente en Joaquín Lorenzo Villanueva, cuya libro "El Tomista en las Cortes", reimprimieron, en 1842, dos conocidos demócratas: Baralt y Fernández Cuesta.

A mi juicio, sin embargo, no conviene identificar el cristianismo de los "demócratas" españoles de mediados del siglo XIX con el "catolicismo liberal", cuyo primer precedente, por cierto, se encuentra más bien en Martínez Marina, a quien Maravall no menciona aquí, pese a haberle dedicado una excelente monografía ${ }^{41}$. Es preciso tener en

37. Apud Maravall, ibidem, pág. 262.

38 lbidem, pág. 261.

39 Ibidem, pág. 262. Sobre este particular, vid. Antonio ELORZA, «Estudio Preliminar» al Curso Político-Constitucional, de Joaquín María López, impartido en 1840 y reeditado por el Centro de Estudios Constitucionales (en adelante, CEC), Madrid, 1987, págs. XX y LIV.

40 Cfr. José Antonio Maravalt, Sobre orígenes $y$ sentido del catolicismo liberal en España, op. cit., pág. 266.

41 José Antonio MARavall, "El Pensamiento Político en España a comienzos del siglo XIX: Martínez Marina", Revista de Estudios Políticos, n. ${ }^{\circ} 81$, Madrid, 1955. Este trabajo puede verse también como «Estudio Preliminar» al Discurso sobre el origen de la Monarquía y sobre la naturaleza del Gobierno español; Francisco Martínez, CEC, Madrid, 1988. Vid, asimismo, Joaquín VARELA SuANzes, Tradición y Liberalismo en Martínez Marina, Facultad de Derecho de Oviedo y Caja Rural 
cuenta que la mayor parte de los "demócratas" se mostraron, como se ha visto, muy hostiles hacia el catolicismo, esto es, hacia la Iglesia católica, no hacia la religión, aunque también hacia las consecuencias políticas que de esta religión extrajeron muchos católicos. Los "demócratas" se manifestaron, como también se ha visto, partidarios de la libertad de cultos e incluso de la aconfesionalidad del Estado. Una postura, ciertamente, muy distinta de la que había sustentado Villanueva, quien en las cortes de Cádiz se caracterizó por defender la confesionalidad católica de la monarquía española. Criterio que coincidía con el de Martínez Marina. Pero además y sobre todo los «demócratas», a diferencia de Villanueva y de Marina, no intentaron interpretar en clave democrático-liberal el escolasticismo tradicional, aristotélico-tomista, base de la filosofía política del catolicismo todavia hoy, quizá porque comprendían que era una vana tarea. Por ello, aunque se designe a Villanueva (y a Marina) como representantes del "catolicismo liberal», no conviene engarzar a los "demócratas" españoles con estos precedentes. Y si la actitud de Villanueva ( $y$ la de Marina) apenas tuvo reflejo en el liberalismo doceañista (con la relativa excepción de los clérigos liberales Torrero, Espiga y Oliveros), como mostré en otra ocasión ${ }^{42}$, mucho menos la tuvo entre el pensamiento democrático posterior.

Los "moderados" y los "liberal-conservadores", en cambio, o muchos de ellos, desde Joaquín Francisco Pacheco a Antonio Cánovas del Castillo, eran tan sólo lo que Maravall denomina «liberales católicos", esto es, liberales que, desde un tímido liberalismo, hostil a la democracia, intentaron conciliar el liberalismo con las doctrinas de la Iglesia Católica o, más bien, mostrar que entre un «liberalismo bien entendido" y el catolicismo oficial (incluido el de Pío IX), no había contradicción alguna. Esta era la realista y ecléctica postura de liberalismo "moderado" y "conservador" español, deseoso de tranquilizar su conciencia tras la desamortización eclesiástica emprendida por el "progresista" Mendizábal en 1837 y tras la firma del Concordato de 1851.

Pese a lo dicho, es preciso tener en cuenta que no todos los "demócratas» españoles compartían el cristianismo. Uno de ellos, y de extraordinaria importancia, Francisco Pi i Margall, no lo compartió

de Asturias, Oviedo, 1983; "Estudio Preliminar» a los Principios Naturales de la Moral, la Politica y la Legislación, de Francisco Martínez Marina, Junta General del Principado de Asturias, Oviedo, 1993, págs. I-CXII.

42 Cfr. Joaquín VARela SuAnzes, La Teoría del Estado en los orígenes del constitucionalismo español (Las Cortes de Cádiz), CEC, Madrid, 1982, págs. 39-42. 
nunca. Sobre este extremo, Juan J. Trías es rotundo al señalar que la crítica de la religión, y más especificamente del cristianismo, ocupa un lugar central en la obra de Pi, desde su Historia de la Pintura (1851), hasta Cartas Intimas, obra póstuma ${ }^{43}$. Ello no impidió desde luego que la obra de Pi estuviese impregnada de un indudable moralismo. Su obra y su vida. Por tantos conceptos ejemplar.

Por otro lado, a partir de 1864, fecha en la que Pío IX dio a la luz el Syllabus, muchos "demócratas" españoles, entre ellos no pocos krausistas, fueron distanciándose, no ya de la Iglesia de Roma, sino de la religión católica, como se refleja en los debates de la Constitución de 1869, cuyo artículo 21 no proclamó, sin embargo, la aconfesionalidad del Estado, ni mucho menos su carácter laico; se limitó a reconocer la libertad de cultos ${ }^{44}$.

43 Cfr. Juan J. TrlAS, «Federalismo y Revolución Burguesa", en Juan J. TRiAS y Antonio EloRza, Federalismo y reforma social en España, op. cit., pág. 52.

44 Lo hizo en los siguientes términos: "La Nación se obliga a mantener el culto y los ministros de la religión católica.

El ejercicio público o privado de cualquiera otro culto queda garantido a todos los extranjeros residentes en España, sin más limitaciones que las reglas universales de la moral y del derecho.

Si algunos españoles profesasen otra religión que la católica, es aplicable a los mismos lo dispuesto en el párrafo anteriorn. 